\title{
An Upsurge of the novel sub-acute respiratory syndrome coronavirus 2 (SARS-CoV-2) pandemic: A systematic review
}

\section{ROHAN SAMIR KUMAR SACHAN ${ }^{1}$, ATUL KUMAR UPADHYAY ${ }^{2}$, ARADHANA DOHROO ${ }^{3}$, ARUN KARNWAL ${ }^{*}$}

${ }^{1}$ Department of Microbiology, School of Bioengineering and Biosciences, Lovely Professional University, Phagwara, Punjab-144411, India

${ }^{2}$ Department of Biotechnology, Thapar Institute of Engineering \& Technology, Patiala, Punjab 147004, India

${ }^{3}$ Baddi University of Emerging Sciences and Technologies, Baddi, Himachal Pradesh- 173405, India

\begin{abstract}
The current pandemic has been declared as a Public Health Emergency of International Concern (PHEIC) by the World Health Organization (WHO) on January 30, 2020. The causative agent of the COVID-19 is Sub-Acute Respiratory Syndrome-Coronavirus-2 (SARS-CoV-2) that causes lung severe disease, is an enveloped RNA virus. The bats being the main zoonotic reservoir of the virus. As of July 9, 2020, the number of cases has around $11,841,326$ cases, with 544,739 death cases worldwide. Surveillance of the asymptomatic carriers, the certain lockdown of the public places, quarantine of 14 days of suspected individuals, or other necessary steps have been taken by each country to limit the coronavirus infection. Many scientists have worked on drug repositioning of already available drugs to compete and kill the virus. The following literature review has been conducted from the publicly available information about the evolutionary relationship, genetics, pathogenesis, clinical manifestation, diagnosis, or laboratory tests of the virus. We have also covered the available control or precautionary measures, and treatment against the virus.
\end{abstract}

Keywords Public Health Emergency of International Concern, World Health Organization, Sub-Acute Respiratory Syndrome-Coronavirus-2, zoonotic, Bats.

To cite this article: SACHAN RSK, UPADHYAY AK, DOHROO A, KARNWAL A. An Upsurge of the novel sub-acute respiratory syndrome coronavirus 2 (SARS-CoV-2) pandemic: A systematic review. Rom Biotechnol Lett. 2021; 26(1): 2195-2206. DOI: $10.25083 / \mathrm{rbl} / 26.1 / 2195.2206$

$\triangle *$ Corresponding author: ARUN KARNWAL, Department of Microbiology, School of Bioengineering and Biosciences, Lovely Professional University, Phagwara, Punjab-144411, India E-mail: arunkarnwal@gmail.com 


\section{Introduction}

The ongoing pandemic outbreak of coronavirus had increased the death rate exponentially over a period of seven months that majorly affects the human respiratory system, and symptoms were similar to that of viral pneumonia (LEILA and SORAYYA, 2020). The unusual viral pneumonia-causing virus was a reservoir in bats and was regarded as a zoonotic virus that infects humans (STEPHEN et al, 2012; DIEGO et al, 2017; RACHEL et al, 2013). The virus has an RNA genome that belongs to the Coronavirinae subfamily (ANTHONY and STANLEY, 2015; GENG et al, 2020). The causative agent of the recent pandemic COVID-19 has been re-named by the International Committee on Taxonomy of Virus (ICTV) as SARS-CoV-2 (Severe Acute Respiratory Syndrome Coronavirus-2) (CERAOLO and GIORGI, 2020). The COVID-19 that was previously named as 2019-nCoV has been threatening the human population across the globe have more death rates since its previous outbreak of SARS in China, and MERS in Saudi Arabia were not much death occurred (PENG et al, 2020; ALEXANDER et al, 2020). Six of the human coronavirus has been identified that includes HCoV-229E, HCoV-HKU1, HCoV-OC43, HCoV-NL63, SARS-CoV, and MERS (Middle-Eastern Respiratory Syndrome) (RACHEL et al, 2013; SHIBO et al, 2020). The first case of COVID-19 was reported in late December 2019. A pneumonia-like outbreak having no clue of its etiology occurred in the city of Wuhan of Hubei province, China, that spread throughout the globe (HONGZHOU et al, 2020).

The coronavirus resides in animals regarded as the reservoir of the virus and affects the respiratory tracts of animals and humans via an intermediate carrier. Until now, three highly pathogenic CoVs of zoonotic origin were identified, having increased virulence that can adapt in humans. Increased virulence was seen since viruses in animals might have evolved, resulting in the strains with high virulence and different biological properties (NICOLA et al, 2020; TAREK and JAMES, 2020). The same scenario might have occurred in the ongoing pandemic where the virus was found to be present in the local fish and wild animal market situated in Wuhan city, China. The common symptoms associated with the virus that was encountered among the humans was a dry cough, dyspnoea, fever, and infiltration in the bilateral lungs (HONGZHOU et al, 2020). The main reservoirs of the virus include bats, equine, cattle, and goats.

In this review, we have summarized the nature of the ongoing pandemic COVID-19, the nature of the virus concerning its clinical characteristics, various signs and symptoms known till now, worldwide cases affected, and lastly, the different methods of precautions, treatment to stop the spread of the virus.

\section{Phylogeny of the virus}

The three viral families withing the order Nidovirales are Coronaviridae, Arteriviridae, and Roniviridae with RNA as genetic material and coronavirus have been placed in the 2196 family Coronaviridae. The virus is an enveloped one having RNA as the genome. Coronaviridae has two sub-families: Coronavirinae and Torovirinae, and SARS-CoV have been placed in Coronavirinae. However, the latter sub-family has viruses that cause enteric infections in horses, cattle, pigs, cats, and goats (CHRISTOPHER et al, 2017).

The sub-family Coronavirinae has been further subdivided among four genera named as Alphacoronavirus, Betacoronavirus, Gammacoronavirus, Deltavirus in which the first two genera viz., Alphacoronavirus and Betacoronavirus infects the humans and the latter two viz., Gammacoronavirus and Deltavirus found to infect the birds (AHMED, 2020). The Betacoronavirus contain many different viruses such as prototype MHV (Mouse Hepatitis Virus), three human viruses that include HCoV-OC43, SARS-HCoV, and HCoV-HKU1, and lastly, SARS-related coronavirus, MERS (CHRISTOPHER et al, 2017; TOMMY, 2006).

The genomic sequence of SARS-CoV-2 has been found $96.2 \%$ identical to that of bat coronavirus (CoV RaTG13) and also reported that the virus originated from the Chinese chrysanthemum bats. It reported that the SARS-CoV-2 was found to be similar to SARS-CoV with a $79.5 \%$ similarity index. The animal pangolin found to play an essential role as an intermediate host to transmit the infection from bats to humans based on the similarity report that suggests $99 \%$ similar sequences between pangolin species and SARS-CoV that were analyzed based on the samples $(>1000)$ along with their metagenomic data (AHMED, 2020; YAN-RONG et al, 2020). So, the SARSCoV-2 belongs to the family of Coronaviridae, sub-family Coronavirinae, order Nidovirales, genera Betacoronavirus, and sub-genus Sarbecovirus.

\section{The genetic makeup of the COVID-19}

The genome of the SARS-CoV-2 is an RNA molecule having 26-32 kilobases and is considered as the largest RNA virus. Upon nucleotide analysis, it was found that this virus has around 29891 nucleotides, which are saved in the database having GenBank accession no. MN908947 that codes for about 9860 amino acids. The genes present in the viral genome has been ordered as (JASPER et al, 2020; RAUJIAN et al, 2020; QINGMEI et al, 2020):

5' UTR --- Replicase (ORF 1a and ORF 1b) --- Spike --Envelope --- Membrane --- Nucleocapsid --- 3' UTR

The 5' UTR (Untranslated Region) is also known as a leader sequence that has a critical role in the gene expression during the viral discontinuous sub-genomic replication (T. et al, 2020). The 5' UTR is the region that contains two-third of the whole genome that has replicase genes. Such replicase genes consist of overlapping open reading frames (ORF) such as ORF 1a and ORF 1b. There are other four open reading frames (ORF) that are downstream to the ORF $1 \mathrm{~b}$, which codes for standard sets of genes expressed in every virus: Spike (S), Envelope (E), Membrane (M), Nucleocapsid (N) (DEIGO et al, 2017; T. et al, 2005; NICOLA and ALESSIO, 2020). These standard sets of genes that codes for structural proteins are 
essential for viral pathogenesis. Apart from structural protein genes, the virus has 16 non-structural proteins (NSPs). The genes for the non-structural proteins are present in the order from nps 1 to nps 16 (DEIGO et al, 2017). As the viral genome reaches the host cell, these nonstructural proteins form a complex known viral replicasetranscriptase complex. They have an essential function in aiding viral replication and sub-genomic transcription. The sub-genomic transcription creates RNAs that help encode structural proteins and several accessory proteins (TIFFANY et al, 2020). So, the major ORFs of the genome includes ORF 1a, ORF 1b codes for replicase enzyme, ORFs encoding S, E, M, N regarded as structural proteins, and ORF $3 b$ and ORF 8 codes for accessory proteins.

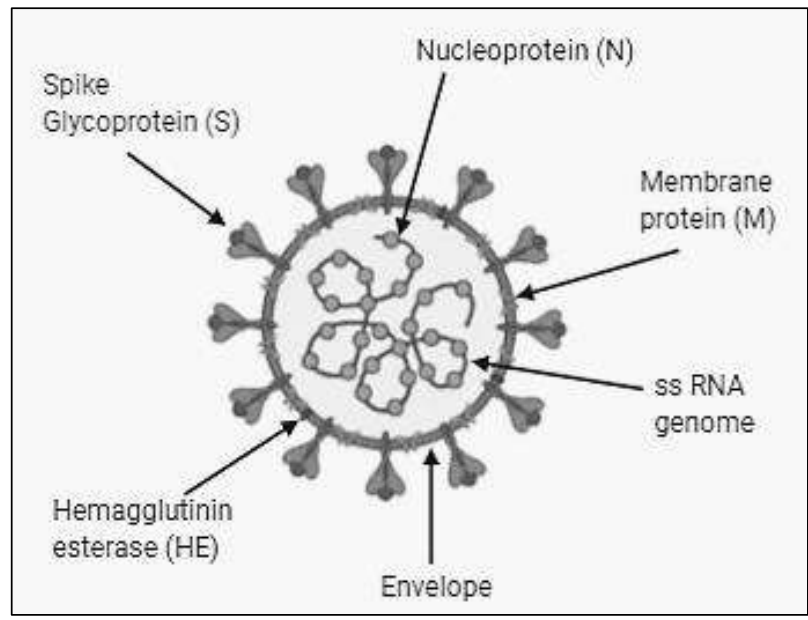

Figure 1. Structure of SARS-CoV-2

There are additional functions of some of the structural proteins, the small membrane (E) protein, also known as envelope protein, aids in viral envelope assembly. The membrane protein (M) is a type III glycoprotein present in abundant and regarded as the "abundant structural component." It has a short amino-terminal ectodomain. The ectodomain consists of a triple spanning transmembrane domain and a long carboxyl-terminal inner domain. The nucleocapsid $(\mathrm{N})$ protein is highly basic due to the presence of phosphor-protein and has a keen role in modulating RNA synthesis. The spike (S) protein plays an essential role in the entry of the virus. The receptor for the viral spikes is specific and present in the host cells, where it binds and contracts to release the viral genome into the host cytosol. Also, the spike protein is a major antigenic determinant that can elicit the immune response in the host cell (NICOLA and ALESSIO, 2020).

The replication or the synthesis of full-length viral RNA starts from the synthesis of full-length negative-sense single-strand RNA. The concentration of negative-sense single-strand RNA is low in the cell that acts as a template for the synthesis of full-length genomic RNA. The CoV transcription starts from synthesizing sub-genomic (sg) negative sense RNA through a discontinuous 3' extension step. It is regulated by transcription regulating sequences (TRSs) present upstream of most of the ORFs and at the 5' end of the genome. The synthesized negative sense RNA serves as a template and forms complementary subgenomic ( $\mathrm{sg}$ ) mRNA from which $5^{\prime}$ end of the mRNA is translated (NICOLA and ALESSIO, 2020). The genome of the SARS-CoV is large, and during the replication, the gene expands. The gene expansion is mediated through a high replication fidelity. Such high replication fidelity is achieved by the use of sets of enzymes: RNA 3' to 5' exoribonuclease (ExoN) and possible endoribonuclease (NendoU) (DEIGO et al, 2017). So, the viral genome requires both structural ORFs and non-structural ORFs to replicate its genome inside the host cell.

\section{Viral Pathogenesis}

The SARS CoV has been regarded as a highly contagious virus, whereas it can survive around two hours in the air (QINGMEI et al, 2020). The pathogenesis of the SARS-CoV and the current SARS-CoV-2 is quite similar. The spike (S) protein plays an essential role in viral entry to initiate the pathogenesis. The spikes belong to the glycoprotein $\mathrm{S} 1$ family binds to the specific receptor called Angiotensin Converting enzyme 2 (ACE 2) for the viral entry into the host cells (AHMED, 2020; TIFFANY et al, 2020). It has been reported that the SARS CoV and SARS CoV-2 have the same affinity towards binding to the receptor. The $\mathrm{S}$ proteins are composed of 2 monomers: $\mathrm{S} 1$, $\mathrm{S} 2$, and arranged as trimers to form a characteristic bulbous crown-like halo surrounding enveloped viral particles. The bulbous head is the characteristics feature of the $S 1$ monomer, whereas the S 2 monomer behaves as a stalk.

Further, the $\mathrm{S} 1$ monomer has two subunits: N-terminal domain (NTD), C-terminal domain (CTD), The CTD helps in the binding of spikes to the receptor ACE 2, which is abundantly present on lung cells and small intestinal cells. For the CoV infection, the cleavage of $\mathrm{S}$ protein into $\mathrm{S} 1$ and $\mathrm{S} 2$ is necessary, done by the proteolytic enzyme trypsin. The successful entry of the virus into the host cell depends solely on the cleavage process of ACE 2 and transmembrane protease/serine subfamily member 2 (TMPRSS2), which activates spike proteins that are present in the airway and alveolar cell areas (TIFFANY et al, 2020).

Once the spikes attach to its specific receptor ACE 2, the viral genome gains entry into the host cell. Upon reaching the cytoplasm, the viral mRNA having open reading frames (ORFs) is translated into proteins. The SARS-CoV-2 has around 14 ORFs, which upon translation forms structural and non-structural proteins needed for virulence. However, genes for non-structural proteins are translated to ORF 1a and ORF $1 \mathrm{~b}$ that produces two large overlap polyproteins known as pp1a and pp1ab. These polyproteins are cleaved in between using papain-like protease (PLpro) and serine-type Mpro, which is a chymotrypsin-like protease (3CLpro) that is encoded by nsp3 (non-structural protein 3) and nsp5 (non-structural protein 5) to from non-structural proteins (nps) 1-11 and 1-16 (PAUL, 2006). The non-structural proteins (nsp) 1-16 forms viral replicase-transcriptase complex (RTC) and transcript sub-genome to produce a transcript of spike (S) protein, envelope (E) protein, membrane $(\mathrm{M})$ protein, and nucleocapsid $(\mathrm{N})$ and upon translation of $\mathrm{S}, \mathrm{E}, \mathrm{M}, \mathrm{N}$ in 
the cytosol of the host cell, these proteins enter the rough endoplasmic reticulum (RER) where these are structurally modified. Once modified, these proteins through the secretory pathway, enter the endoplasmic reticulum - Golgi apparatus intermediate complex (ERGIC) where the $\mathrm{S}$ proteins get extensively modified through $\mathrm{N}$-glycosylation and get forms trimers. The ERGIC is also considered a site for viral particle assembly. The nucleocapsid is assembled with other structural proteins and forms a small wallet that is released from the host cell through cell exocytosis (TIFFANY et al, 2020; INDWIANI and YSUAFIL, 2020).

The non-structural proteins (nps) are essential for the processing of the viral genomes. The table (1) summarizes the role of different non-structural proteins (nps) in infection (ANTHONY and STANLEY, 2015; INDWIANI and YSUAFIL, 2020):

Table 1. Role of different non-structural proteins (nps) in infection

\begin{tabular}{|c|c|}
\hline Non-structural proteins (nps) & Functions \\
\hline nsp1 & $\begin{array}{l}\text { - } \text { Promotes the degradation of cellular mRNA } \\
\text { - Blocks innate immune response } \\
\text { - Blocks host cell translation } \\
\text { - Inhibit interferon (INF) signaling }\end{array}$ \\
\hline nsp2 & - Binds to pro-inhibition proteins \\
\hline nsp3 & $\begin{array}{l}\text { - A large multi-domain transmembrane protein } \\
\text { - Ub11 and Ac domain of the protein interact with } \mathrm{N} \text { protein } \\
\text { - Promote cytokine expression } \\
\text { - Cleaves viral polyprotein } \\
\text { - Blocks innate immune response }\end{array}$ \\
\hline nsp4 & $\begin{array}{l}\text { - A potential transmembrane scaffold protein } \\
\text { - Essential for the proper structure of DMVs (Double membrane } \\
\text { vesicles) }\end{array}$ \\
\hline nsp5 & - A Mpro (protease) that cleaves viral polyprotein \\
\hline nsp6 & - Needed for proper structure pf DMVs \\
\hline nsp7 & $\begin{array}{l}\text { - Forms hexadecameric complex with nsp8 } \\
\text { - Act as processivity clamp for RNA polymerase }\end{array}$ \\
\hline nsp8 & $\begin{array}{l}\text { - Forms hexadecameric complex with nsp7 } \\
\text { - May act as primase }\end{array}$ \\
\hline nsp9 & - An RNA binding protein (a phosphatase) \\
\hline nsp10 & $\begin{array}{ll}\text { - } & \text { Act as a cofactor for nsp14 and nsp16 } \\
\text { - } & \text { Forms hexadimer with nsp14 and nsp16 } \\
\text { - } & \text { Stimulate ExoN (exonuclease) and 2-O-MT (Coronaviral 2' ortho- } \\
\text { Methyltransferase activity) }\end{array}$ \\
\hline nsp12 & - An RNA dependent RNA polymerase enzyme \\
\hline nsp13 & - An RNA helicase and 5' triphosphatase activity \\
\hline nsp14 & - An ExoN (exoribonuclease) for proofreading activity \\
\hline nsp15 & - An endoribonuclease (NendoU) activity \\
\hline nsp16 & $\begin{array}{l}\text { - Shields viral genome from host MDA5 (melanoma differentiation- } \\
\text { associated protein 5) recognition } \\
\text { - Inhibit innate immune regulation }\end{array}$ \\
\hline
\end{tabular}

So, SARS-CoV-2 virus spikes and ACE 2 receptor of the host plays a vital role in the entry and induction of the pathogenesis. However, the non-structural proteins also have a crucial role in the virulence of the disease.

\section{Clinical manifestations and Pathology}

The virus incubation period is around 4-8 days after the infection (QINGMEI et al, 2020). It has been seen that the SARS-CoV-2 generally causes infection in the lower respiratory tract. The most common symptoms encountered by the person are fever, fatigue, dry cough, sore throat, sneezing, and myalgia (muscle pain), which is followed by rhinobyon (nasal plug), rhinorrhea (running nose), pharyngalgia (pain in the pharynx), and diarrhea. There are some of the less common symptoms associated with the infection, like the production of sputum, headache, hemoptysis (coughing of blood originating from the respiratory tract), and abdominal pain. In most of the cases, within one week, patients encounter yet another medical condition such as dyspnea (shortness of breath) and hypoxemia (low level of oxygen in the blood) that eventually leads to acute respiratory distress syndrome (ARDS) followed by septic shock, metabolic acidosis, and multiple organ failure leading to multiple organ dysfunction syndromes (MODS). Some reports suggest coagulation dysfunction, along with prolonged thrombin time (DAURI et al, 2020; HARAPAN et al, 2020). 


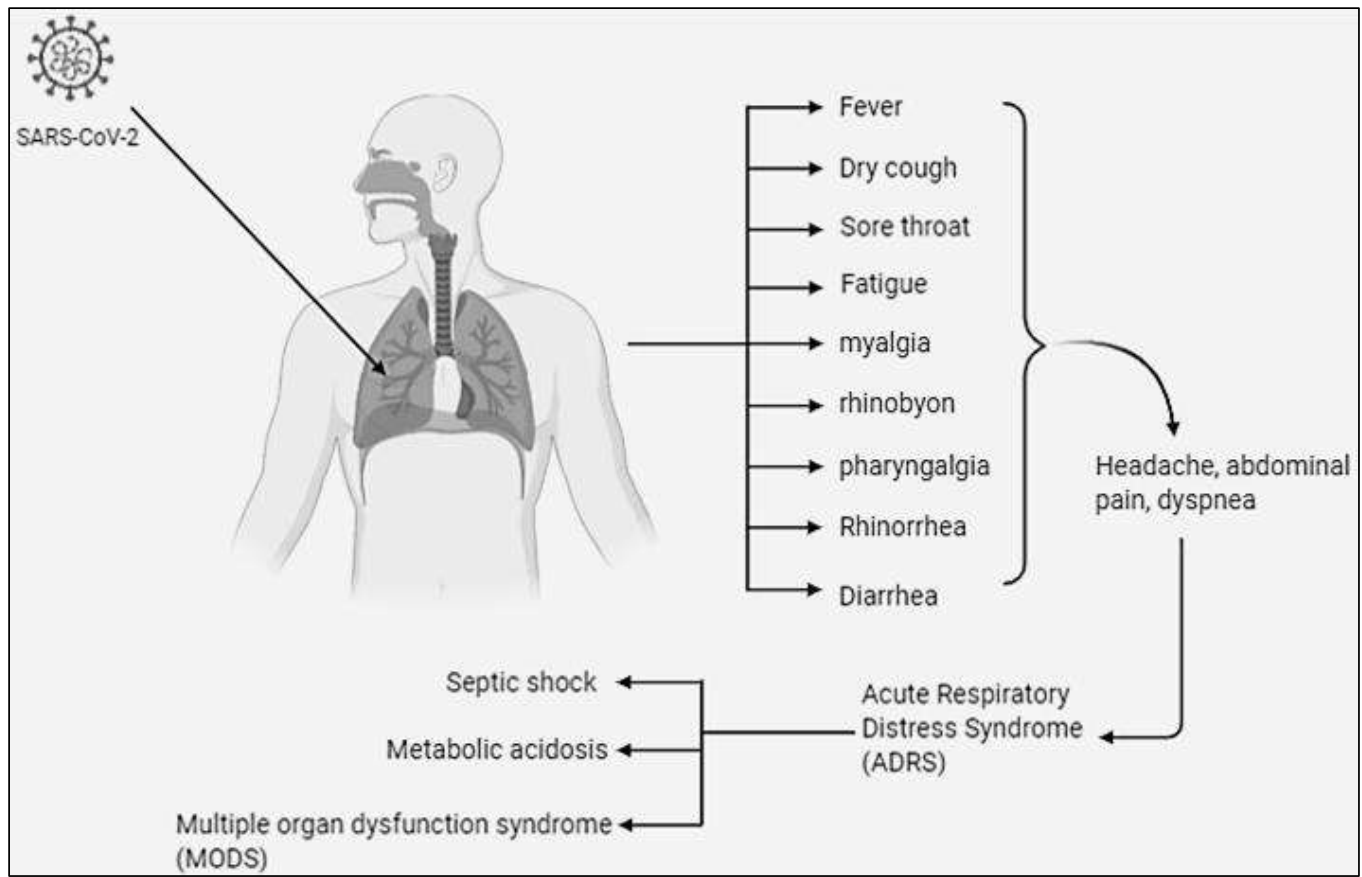

Figure 2. The summarized manifestation of SARS-CoV-2 affecting the human lower respiratory system.

Most of the risk factors has been seen in adult males rather than females having a median age of 34 to 59 years (HARANPAN et al, 2020). The risk of infection increases in people with co-infections like cardiovascular and cerebrovascular diseases and people with diabetes or people are at high risk of infection, which is already infected with bacterial or fungal diseases (coinfection) (NANSHAN et al, 2020). The children or infants have shown decreased clinical manifestation than the adults, and the pregnant women showed the same clinical conditions with those of infected people (HARAPAN et al, 2020). However, There have been no reports suggesting any pathology risk assessment to the fetus of the pregnant women (KULDEEP et al, 2020).

There are inflammatory damage or increased proinflammatory cytokines associated with the SARS-CoV-2 infection. The list of common cytokines associated with the SARS-CoV infection mentioned in the table (2) (CHAOLIN et al, 2020; ALLISON and RALPH, 2012):

Table 2. List of common cytokines associated with the SARS-CoV infection

\begin{tabular}{|c|c|}
\hline Cytokine & Function \\
\hline Interleukin-1 (IL-1) & $\begin{array}{l}\text { - } \text { Promote fever and sepsis } \\
\text { - } \text { Production of inflammatory cytokines }\end{array}$ \\
\hline Interleukin-2 (IL-2 & - Regulates the activity of leukocytes, especially lymphocytes \\
\hline Interleukin-6 (IL-6) & $\begin{array}{l}\text { - Stimulate acute phase protein synthesis } \\
\text { - Enhance the production of neutrophils in bone marrow }\end{array}$ \\
\hline Interleukin-7 (IL-7) & - Associated with the activity of the adaptive immune system \\
\hline Interleukin-12 (IL-12) & $\begin{array}{l}\text { - Develops Th } 1 \text { response } \\
\text { - A potent inducer of TNF- } \alpha \text { by T and natural killer (NK) cells }\end{array}$ \\
\hline Interleukin-1 $\beta$ (IL-1 $\beta)$ & - Generation of systemic or local response to the infection \\
\hline Interleukin- $\beta$ (IL- $\beta$ ) & • \\
\hline Interferon- $\gamma($ INF- $\gamma)$ & - Primary activation of macrophages \\
\hline Interferon- $\gamma$ Protein 10 (INF- $\gamma$ P10) & $\begin{array}{l}\text { - Also known as CXCL10 } \\
\text { - Activity in chemo-attraction of monocytes or macrophages, } \\
\text { T cells/dendritic cells/NK cells }\end{array}$ \\
\hline $\begin{array}{l}\text { Macrophage inflammatory protein } \\
\text { 1A (MIP1A) }\end{array}$ & $\begin{array}{ll} & \text { Recruits inflammatory cells } \\
\text { - } & \text { Inhibits stem cells } \\
\text { - Wound healing } \\
\end{array}$ \\
\hline Tumor necrosis factor- $\alpha$ (TNF- $\alpha)$ & - Used in signaling for necrosis or apoptosis \\
\hline $\begin{array}{l}\text { Monocyte chemoattractant protein } 1 \\
\text { (MCP1) }\end{array}$ & - Regulates migration and infiltration of monocytes/macrophages \\
\hline $\begin{array}{l}\text { Granulocyte colony-stimulating } \\
\text { factor (GCSF) }\end{array}$ & - Signaling for increasing blood cells number \\
\hline
\end{tabular}


While some of the laboratory findings detected few early forms of the disease such as leukocytopenia, lymphopenia, mild elevated C-reactive proteins, increased level of aspartate aminotransferase, ESR in blood samples, and low level of procalcitonin had been seen in the blood (KULDEEP et al, 2020). However, in some of the severe cases, high-level leukocytes, especially granulocytes as well as D-dimer, creatine kinase, and creatine has been reported. The blood samples also showed elevated IgM antibodies level during the first week of the infection and later declined. The increased levels were because the IgM antibodies appear in the first line of the humoral immune response during the infection. Later, IgG antibodies took over the IgM antibodies that remained in the blood for over two months (HOU et al, 2020).

During the chest computerized tomography (CT) of the lungs showed bilateral pneumonia that has characteristics feature with multiple patchy shadows showing ground-glass opacity and interstitial infiltration in the chest and subsegmental consolidation (DAURI et al, 2020). Also, the radiological report of a study showed ground-glass opacities of the child's chest, and the child was an asymptomatic carrier of the disease COVID-19 (JASPER et al, 2020). However, the virus shedding was found from nasopharynx after seven days of infection, and many reports also suggest the virus detection in stool and blood. Many past studies have shown that the coronavirus family also invade the brain system. However, the virus invasion in the brain was most likely if the patient has a history of brain disorders (VALLAMKONDU et al, 2020). Currently, there are many hypotheses regarding SARS-CoV-2 involvement in disturbing the brain function. The presence of AEC2 in the CNS (Central Nervous System) enables the SARS-CoV-2 to enter the brain causes immune response through exacerbating stimuli at the angiotensin 2 receptor. This causes encephalitis and neural damage along with vascular injury and blood-brain barrier destruction (DE SOUSA et al, 2020).

\section{Transmission}

It has been seen that the bats are the natural host of the virus, pangolins, and snakes as the intermediate host, and the humans are the primary host for the infection. However, it has been debunked that the snakes have or being the intermediate host of the SRAS-CoV-2 (LI-SHENG et al, 2020). Also, no reports until now suggest the transmission of the virus through pests like mosquitos or blood-feeding arthropods (ESLAMI and JALILI, 2020). The primary and important mode of transmission of SARS-CoV-2 is respiratory droplets. The person with pneumonia infected by SARS-CoV-2 has been reported to transmit via respiratory droplet (DI et al, 2020). The transmission can be through aerial droplets or contact that leads to personto-person transmission.

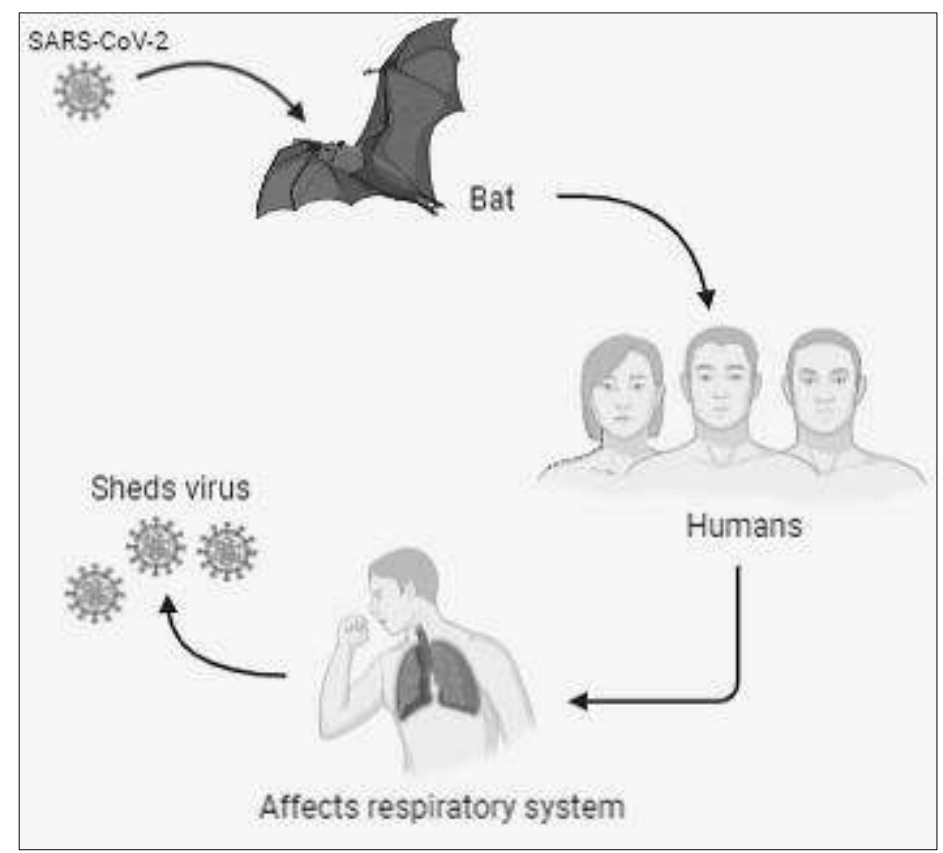

Figure 3. SARS-CoV-2 transmission from bat to humans

The primary source for the person-to-person transmission is possibly the asymptomatic carriers of SARSCoV-2. The health care personnel or community contacts can be the route for transmitting the virus particles (ISSAC et al, 2020). It has been reported that the virus can have both respiratory and fecal-oral transmission potential. However, the research of ?? suggested indirect contact and airborne source can be a more significant route of transmission than the transmission through fecal or body fluids based on the property of the virus having a hard shell that the capability to shed more viral particles (GERARD et al, 2020). The close contact with the familial households is regarded as the secondary transmission for the virus where the most of the person is an asymptomatic carrier based on the diagnostic 
test of RT-PCR that had gone for quarantine for at least two weeks period. It has been reported that the family with more members are at high risk and to transmit the disease. The most common symptoms seen most in such cases are fever, cough, fatigue, myalgia, and dyspnea (LI-SHENG et al, 2020). The clusters of infected family members where one member has an infection and had transmitted the infection to all the other members and even the hospitalassociated transmission where the health-care or medical workers are at high risk to get or transmit the infection. Such infection can be transmitted from the source like fomites (inanimate objects having pathogen) that includes cups, spoons, pencils, bath faucet handles, toilet flush levers, doorknobs, light switches, handrails, elevator buttons, television remote controls, pens, touch screens, common-use phones, keyboards, and computer mice, coffeepot handles (ZHONGLIANG et al, 2020).

Another mode of transmission has been reported in pregnant women: vertical transmission, where the infection transmitted from infected mother to their child. Such transmission has devastating consequences on the neonates. Vertical transmission during antenatal or prepartum has been reported; however, transmission during perinatal or postnatal has seen to have consequences. But no intrauterine transmission has been seen from pregnant women to neonates (KULDEEP et al, 2020).

Reports suggested the presence of SARS-CoV-2 in stool, gastro-intestinal tract, saliva, and urine based on the application of bioinformatics. It has also been reported that the virus under a long latency period affects the transmission of the viral particles, such as a maximum latency period of around 24 days may increase the risk of the transmission of the virus (LI-SHENG et al, 2020).

\section{Diagnosis and Laboratory test}

Certain guidelines need to be followed before any diagnostic approach used for the detection of the SARSCoV-2. Such guidelines have been surveillance under WHO and need to be stringently followed (WHO, 2020). WHO has also published the recommendation of certain cases that need to be screened as to get more common causes of SARS-CoV-2 respiratory illness that are based on season and location, and if such cases are found to be negative are sent to different referrals laboratories for detection of SARS-CoV-2. The cases that require diagnosis are (i) a person having a history of fever, cough, along with severe acute respiratory illness (ARI) need to be hospitalized. Such cases have no other etiology but require to collect information regarding any history of travel or evidence in China during 14 days time period before the onset of the symptoms. (ii) patients with acute respiratory illness (ARI) and at least one of the following causes during 14 days before the onset of symptoms (HARAPAN et al, 2020).

1. Contact or worked with the people having confirmed or probable cases of the infection.

2. Attended a health care facility where the patients of confirmed cases were treated.
3. Came in contact with the cases that are probable of the infection for whom SARS-CoV-2 detection test was inconclusive, however, found to be positive using pan coronavirus assay.

4. Contact with the confirmed case irrespective of any clinical signs and symptoms.

Such criteria are met, CDC recommends the collection of the specimen. The specimen collected should be from the upper respiratory tract (URT) that includes nasopharyngeal and oropharyngeal swabs and less common lower respiratory tract (LRT) include sputum, tracheal aspirate, and bronchoalveolar lavage (ANITA et al, 2020).

Based on the diagnosis of such cases that meets the guidelines of the WHO, the suspected cases are screened for the infection using a nucleic acid amplification test (NAAT) like RT-PCR (CHAN et al, 2020). For the screening and detection of SARS-CoV-2, there are two fragments, also called a gene of interest: ORF 1a and ORF $1 \mathrm{~b}$ and secondary gene fragment of nucleocapsid $(\mathrm{N})$ protein. The sample containing viral genome are amplified under the prescribed conditions that include treating gene fragments at $50^{\circ} \mathrm{C}$ for 15 minutes, $95^{\circ} \mathrm{C}$ for 3 minutes, which followed by 40 cycles of $95^{\circ} \mathrm{C}$ for 15 minutes, and $60^{\circ} \mathrm{C}$ for 30 seconds. The cycle threshold $(\mathrm{Ct})$ is set for the amplification process. After the amplification process, the results are interpreted based on the $\mathrm{Ct}$ values (RUI et al, 2020):

Table 3. $\mathrm{Ct}$ value of amplification process

\begin{tabular}{|c|c|}
\hline Cycle threshold $(\mathbf{C t})$ values & Interpretation \\
\hline$>37$ & Positive \\
\hline$\leq 40$ & Negative \\
\hline $37<\mathrm{Ct}>40$ & Retest \\
\hline
\end{tabular}

Another diagnostic test recommended by WHO is the whole viral sequencing for the confirmation of the presence of the virus in the percentage of the specimen. Such sequences can be reported to the public access databases with the repository of the available genetic sequences. The databases also include GISAID that protects the right to submitting party (CHU et al, 2004).

The antibodies-based detection of the SARS-CoV-2 is an alternative choice for rapid analysis. Many serological tests for the detection of the virus have been evaluated. The potential $\operatorname{IgM}$ and $\operatorname{IgG}$ antibodies produced during the infection have been a possible marker for detecting the virus (THEEL et al, 2020, HOU et al, 2020). The widely used serological or immunological test for detecting $\operatorname{IgM}$ level in the SARS-CoV-2 infection is Enzyme-Linked Immunosorbent Assay (ELISA). Such ELISA kit uses recombinant nucleocapsid $(\mathrm{N})$ and spike $(\mathrm{S})$ proteins of SARS-CoV-2 that quantitatively detects IgM and IgG antibodies in the blood plasma (BUNDSCHUH et al, 020).

\section{Control and Precautionary measures}

There have been different strategies among different sectors like healthcare facilities, community level, or personal level that need to be implemented to tackle the 
SARS-CoV-2 transmission. The health care facility is more prone to contract the infection which is needed to follow the following guidelines after the cases are identified carefully and bought to the facility for the treatment process (HARAPAN et al, 2020):

1) The COVID-19 ward should be isolated, and regular contact tracing must be monitored.

2) The suspected cases having symptoms like running nose, fever, dry cough, shortness of breath at the health care facility must need to wear a mask to contain the virus and strictly adhere to the triage procedure.

3) The suspected cases or the confirmed cases should not allow waiting with the other patients that are seeking medical care at the facility due to an increased rate of infection in such close contact. The confirmed cases or the suspected cases need to be placed separately in a fully ventilated rooms approximately 2 meters apart from other patients.

4) The severe cases of the COVID-19 must be kept in separate single rooms having negative air pressure of a minimum of six air per hour rate.

5) The exhaust air of such COVID-19 ward should have a filter. The recommended filter for the exhaust is high particulate efficiency air (HEPA) filter.

6) The medical personnel or workers should have individual personnel protective equipment (PPE) with gloves, a gown, disposable N95 face-mask for the protection while attending the patients to avoid the infection.

7) Once the cases are recovered or discharged, the room must be decontaminated or disinfected before the new admission of the patients. The workers need to have PPE for this work too.

At the community level, the guidelines that need to be followed for the stop of the infection are isolating the suspected people from the community is the primary step to interrupt the transmission. The suspected people having travel history or the common symptoms and their close contact must be quarantined for at least 12-14 days. Awareness should be created by educating people about unusual signs and symptoms like shortness of breath, chronic dry cough, and fever. Such awareness can identify the cases and sent them to the medical care facility for detection and treatment. However, if the transmission happens to be larger in the larger community, the primary steps taken should involve mitigating the large/small social gathering, closing the institutional places like schools, universities, colleges, and coaching institutes for the temporary period.

At the personal level, there are some pointer or collective summarized steps taken for the self-care to avoid transmission of the infection (AHMED, 2020):

1) Momentarily hand washing with the soap to sanitize for at least 20 seconds or using alcohol-based hand sanitizer is the primary step for self-care.

2) The use of disinfection using $70 \%$ alcohol or $0.5 \%$ bleach solution at home to disinfect various inanimate objects like doorknobs, floors, tables, mobile phones, or any other items regularly.
3) Avoid or refrain touching of the eyes, nose, and mouth. If touched, then sanitized your hands through soap or an alcohol-based sanitizer.

4) Performing respiratory hygiene like cough or sneeze into a bent elbow or the use of tissue paper. The tissue must be immediately disposed-off and wash hands.

5) The person complains about the respiratory symptoms should wear a surgical or medical mask or N95 mask and should be quarantined in a separate room for at least 12 days. The person should avoid coming in contact with the other family members

6) Avoid social gatherings and maintain a distance of 6.5 feet ( 2 meters), avoid smoking, and drink plenty of water.

7) Being a responsible citizen, share your travel history if they have traveled back from any country during the pandemic situation. People should avoid travel during such time to be safe.

So, the possible mitigating steps like focusing on public health, contact tracing quarantine people, surveillance of asymptomatic carriers, diagnosis, isolation, and management of the infected patients, and significant steps to stop community spread of the disease.

\section{Treatment}

The death rate in the case of SARS-CoV-2 infection has not yet declined but increased over the past four months since the outbreak. There have been no specific therapies that can be used to treat COVID-19 patients. It has been seen that the SARS-CoV-2 functional proteins for the process of virus replication and assembly are somewhat similar to Human Immunodeficiency Virus (HIV). The drugs responsible for HIV protease inhibitors may be a possible way to treat SARS-CoV-2 infection (RUI et al, 2020). According to the latest guidelines, the drugs lopinavir or ritonavir (LPV/r) that showed an effective treatment against the previous outbreak of SARS-CoV and MERS can be used to treat the COVID-19 patients. These drugs interfere in the proteolysis process in the SARSCoV-2 replication cycle (CHU et al, 2004; HISHAM et al, 2019). Through computational analysis such as homology modeling and molecular docking techniques, nelfinavir drug has shown an effective way to treat the patients (ZHIJIAN et al, 2020).

The reports suggest the use of Menstrual bloodderived MSCs (Mesenchymal Stem Cells) as an alternative treatment or therapy process to treat severe COVID-19 patients. This process of treatment showed a lower mortality rate in H7N9-induced ARDS (Acute Respiratory Distress Syndrome) as it has been proven that the pathological feature of SARS-CoV-2 associated ARDS shown similar symptoms to that of H7N9 induced ARDS. The MSCs improve the lung function by improving antiinflammatory effects in the acute injury of the lungs seen in the mouse model (JIAJIA et al, 2020).

The most common approach used worldwide in making the drugs for the treatment for the SARS-CoV-2 
infection is drug repositioning. The drug repositioning involves redirecting, repurposing, and reprofiling of the already available drugs and has emerged as an effective possible way to make drugs for the treatment (ASHISH, 2020; MARRISA et al, 2020). For instance, the use of chloroquine (CQ) or its hydroxyl analog hydroxychloroquine (HCQ) as an antiviral drug. The drug increases the $\mathrm{pH}$ in acidic organelles such as lysosomes, endosomes, Golgi vesicles of the SARS-CoV-2. The drug also inhibits the entry of the virus into the host cell through a $\mathrm{pH}$-dependent mechanism, or the drug might inhibit the post-translational process of the viral envelope glycoproteins inside the endoplasmic vesicles and trans-Golgi network (JEAN-MARC et al, 2007; PHILIPPE et al, 2020). The drug repositioning has been reported for the drugs chloroquine or hydroxychloroquine that has been associated with other drugs such as azithromycin, teicoplanin, remedesivir, nitazoxanide, and metformin (MARRISA et al, 2020). Bafilomycin A1, a macrolide, has been proven to be a promising drug candidate, an endo/lysosomal $\mathrm{V}$-ATPase inhibitor and interrupts the functions of angiotensin-converting enzyme 2 (ACE 2). The ACE 2 is a receptor through which the SARS-CoV-2 gains entry into the host cell; blocking of such receptor inhibits the entry and stop the viral cycle (HONGLIANG et al, 2006). The drug remdesivir, an adenosine analog used against the Ebola virus, has proven to be more effective against SARSCOV-2. This virus incorporates into the nascent RNA chain of the virus and prematurely terminates the translation process (MANLI et al, 2020). An immunosuppressive agent, tocilizumab, which was used previously to treat rheumatoid arthritis (RA) has been shown to be an effective drug tested in vivo that reduces clinical symptoms of the SARS-CoV-2 infection (XIAOLING et al, 2020). Another group of drugs such as ribavirin used to treat respiratory syncytial virus (RSV) infection, telbivudine used to treat hepatitis B, vitamin B12, and nicotinamide is the possible drugs that target Mpro of the SARS-CoV-2 and inhibit it (MAHMOUD and MOHAMMED, 2020).

Another method used for the treatment of the SARSCoV-2 infection has been suggested by increasing the aerobic capacity that could produce a short term yet safe improvement in the function of the immune and respiratory system. Increasing the aerobic capacity for the treatment has three broad mechanisms (AYMAN and MOTAZ, 2020):

1) It improves the respiratory system in terms of antibiotics, antioxidants, and antimycotic analog to restore the normal lung tissue elasticity and strength.

2) It increases immunity through increasing the levels of the immune cells such as T-lymphocytes, macrophages, monocytes, neutrophils; immunoglobulins; and C-reactive proteins (CRP) and decreasing the anxiety and depression by improving the rebalance of T-helper 1 and T-helper 2 cells.

3) As a protective barrier that can decrease the risk factors of SARS-CoV-2 infections.

\section{Conclusion/Future aspects}

The SARS-CoV-2 infection has now been reported as an International Public Health Problem (IPHP) due to the rapidly increased rate of transmission across the whole world. There is a need to increase the surveillance around the respective countries, and more detection of the cases need to be done to bring out the actual numbers. More awareness needs to be created among the people with the rapid advances about the infection in terms of changes in the clinical characteristics. However, many significant steps have been taken by individual countries like surveillance of the people with travel history, necessary lockdown to avoid social gathering, increased public health care center for treatment, etc. It is also personal duty if the person has respiratory distress must report to the health facility as soon as possible to start the treatment procedure. If someone has traveled from any part of the country, must undergo selfquarantine to avoid unnecessary spreading of the disease.

The primary concern must be more towards the drug discoveries or the vaccines. More advances regarding the sensitivity of the detection test must be there like there is no such serological test until now to detect the virus. Also, the coronavirus family has a history of invading the central nervous system causing severe brain damage. Hence, research regarding the serological approach must be carried out for even more early detection and identify the role of current SARS-CoV-2 in brain damage.

\section{Executive summary}

The pandemic COVID-19 has a very significant effect on the humans which has been spread through the bats sold in Wuhan city of China. The SARS-CoV-2 has an RNA genome that is enclosed in an envelope. The important antigenic determinant site for the infection are membrane (M) protein and spike (S) protiens that has an ability to elicit the immune response in the humans. The viral spikes have access to the host angiotensin converting enzyme 2 (ACE 2) receptor for its entry into the cell. The human-tohuman transmission through close cotnatc with the infected person or the asymptomatic carrier of the virus has led to increased transmission of the infection that has even increased the number of the cases of the patients across the countries. The onset of the infection starts with initial symptoms like dry cough, dyspnea, and high fever. In severe cases of the SARS-CoV-2 infection the patients encounter multiple co-infection with bacteria or fungi. The infection affects the lower respiratory tract of the humans and even multiple organ failure has been reported in severe cases. The clinical or radiological laboratory finding such as CT scan of the lungs often show opacity due to the infection. There is no such age-group differentiation seen in the infection, however, man with smoking habit are prone to the infections, infection in children has less clinical manifestation, and in the case of pregnant women the fetus are always at high risk to get infection. The virus has ben reported to transmit from nasal droplets of the infected and has around 96 hours survival 
time on the fomites. There has been precautionary steps or guidelines given by World Health Organization (WHO) like regular sanitizing hands with soaps or alcohol-based hand sanitizers, avoid touching eyes, mouth, and nose. Person having any respiratory symptoms must need to wear mask and if possible gloves to avoid spread of the infection to other people. Use of tissues before sneeze or cough and immediate disposing of the same and many such other guideline to keep the people free from the infection. The respective president of the countries has even lockdown areas to avoid mass gathering. In the medical facility, many drugs such as chloroquine or hydroxychloroquine, remdesivir and many other anti-viral durgs that has been repositioned are used for the treatment of the COVID-19 patients.

\section{Acknowledgment}

The authors acknowledge their sincere thanks to the colleague who has given critical comments on this work.

\section{Conflict of Interest}

No competing interest was found during this work.

\section{Funding/Support}

No funding was used for this work.

\section{References}

1. ABD EL-AZIZ TM, STOCKAND JD. Recent progress and challenges in drug development against COVID19 coronavirus (SARS-CoV-2)-an update on the status. Infect Genet Evol. 2020; 83: article no. 104327. doi: https://doi.org/10.1016/j.meegid.2020.104327

2. AL-QAHTANI AA. Severe Acute Respiratory Syndrome Coronavirus 2 (SARS-CoV-2): Emergence, History, Basic and Clinical Aspects. Saudi J Biol Sci. 2020. doi: https://doi.org/10.1016/j.sjbs.2020.04.033.

3. BUNDSCHUH C, EGGER M, WIESINGER K, GABRIEL C, CLODI M, MUELLER $\mathrm{T}$ et al. Evaluation of the EDI enzyme linked immunosorbent assays for the detection of SARS-CoV-2 IgM and IgG antibodies in human plasma. Clin Chim Acta. 2020. doi: https://doi.org/10.1016/j.cca.2020.05.047

4. BURRELL CJ, HOWARD, CR, MURPHY FA. Coronaviruses. Fenner and White's Medical Virology, Academic Press, Massachusetts, $5^{\text {th }}$ edition, 2017.

5. CERAOLO C, GIORGI FM. Genomic variance of the 2019-nCoV coronavirus. J Med Virol. 2020, 92(5): 522-528. doi: https://doi.org/10.1002/jmv.25700

6. CHAN JFW, KOK KH, ZHU Z, CHU H et al. Genomic characterization of the 2019 novel human-pathogenic coronavirus isolated from a patient with atypical pneumonia after visiting Wuhan. Emerg Microbes Infec. 2020, 9(1): 221-236. doi: https://doi.org/10.1080/ 22221751.2020.1719902
7. CHAN JFW, YUAN S, KOK KH, TO KKW et al. A familial cluster of pneumonia associated with the 2019 novel coronavirus indicating person-to-person transmission: a study of a family cluster. Lancet. 2020, 395(10223): 514-523. doi: https://doi.org/10.1016/ S0140-6736(20)30154-9

8. CHEN J, HU C, CHEN L, TANG L et al. Clinical study of mesenchymal stem cell treating acute respiratory distress syndrome induced by epidemic Influenza A (H7N9) infection, a hint for COVID-19 treatment. Eng. 2020. doi: https://doi.org/10.1016/j.eng.2020.02.006

9. CHEN N, ZHOU M, DONG X, QU J et al. Epidemiological and clinical characteristics of 99 cases of 2019 novel coronavirus pneumonia in Wuhan, China: a descriptive study. Lancet. 2020, 395(10223): 507-513. doi: https://doi.org/10.1016/S0140-6736(20)30211-7

10. CHEN Y, LIU Q, GUO D. Emerging coronaviruses: genome structure, replication, and pathogenesis. J Med Virol. 2020, 92(4): 418-423. doi: https://doi.org/ 10.1002/jmv.25681

11. CHU CM, CHENG VCC, HUNG IFN, WONG MML et al. Role of lopinavir/ritonavir in the treatment of SARS: initial virological and clinical findings. Thorax. 2004; 59(3): 252-256. doi: https://doi.org/10.1136/ thorax.2003.012658

12. COLSON P, ROLAIN JM, RAOULT D. Chloroquine for the 2019 novel coronavirus. Int J Antimicrob Ag. 2020; 55(3), article no. 105923. doi: https://doi.org/ 10.1016/j.ijantimicag.2020.105923

13. DE SOUSA AK, DE AGUIAR MAGALHÃES D, DOS SANTOS FERREIRA J, DOS REIS BARBOSA AL. SARS-CoV-2-mediated encephalitis: role of AT2R receptors in the blood-brain barrier. Med Hypotheses, (2020); 110213. doi: https://doi.org/10.1016/j.mehy. 2020.110213

14. DECARO N, LORUSSO A. Novel human coronavirus (SARS-CoV-2): a lesson from animal coronaviruses. Vet Microbiol. 2020; article no. 108693. doi: https://doi.org/10.1016/j.vetmic.2020.108693

15. DHAMA K, PATEL SK, PATHAK M, YATOO MI et al. An update on SARS-CoV-2/COVID-19 with particular reference to its clinical pathology, pathogenesis, immunopathology and mitigation strategies. Travel Med Infect Dis. 2020; article no. 101755. doi: https://doi.org/10.1016/j.tmaid.2020.101755

16. ESLAMI H, \& JALILI M (2020). The role of environmental factors to transmission of SARSCoV-2 (COVID-19). AMB. 2020; 10(1): 1-8. doi: https://doi.org/10.1186/s13568-020-01028-0

17. FEHR AR and PERLMAN S, MAIER HJ, BICKERTON E and BRITTON P. Coronaviruses: an overview of their replication and pathogenesis, Coronaviruses, Humana Press, New York, 2015.

18. FORNI D, CAGLIANI R, CLERICI M, SIRONI M. Molecular evolution of human coronavirus genomes. Trends Microbiol. 2017; 25(1): 35-48. doi: https://doi.org/10.1016/j.tim.2016.09.001 
19. GHINAI I, MCPHERSON TD, HUNTER JC, KIRKING HL et al. First known person-to-person transmission of severe acute respiratory syndrome coronavirus 2 (SARS-CoV-2) in the USA. Lancet. 2020. doi: https://doi.org/10.1016/S0140-6736(20)30607-3

20. Global Surveillance for human infection with novel coronavirus (2019-nCoV). In: World Health Organization; 2020.

21. GOH GKM, DUNKER AK, FOSTER JA, UVERSKY VN. Shell disorder analysis predicts greater resilience of the SARS-CoV-2 (COVID-19) outside the body and in body fluids. Microb Pathog. 2020; article no. 104177. doi: https://doi.org/10.1016/j.micpath.2020. 104177

22. GORBALENYA AE, BAKER SC, BARIC RS, DE GROOT RJ et al. The species Severe acute respiratory syndrome-related coronavirus: classifying 2019-nCoV and naming it SARS-CoV-2, Nat Microbiol. 2020. doi: 10.1038/s41564-020-0695-Z

23. GRAHAM RL, DONALDSON EF, BARIC RS. A decade after SARS: strategies for controlling emerging coronaviruses. Nat Rev Microbiol. 2013; 11(12): 836848. doi: https://doi.org/10.1038/nrmicro3143

24. GUO YR, CAO QD, HONG ZS, TAN YY et al. The origin, transmission and clinical therapies on coronavirus disease 2019 (COVID-19) outbreak - an update on the status. Mil Med Res. 2020; 7(1): 1-10. doi: https://doi.org/10.1186/s40779-020-00240-0

25. HAN Q, LIN Q, JIN S, YOU L. Recent insights into 2019-nCoV: a brief but comprehensive review. J Infection. 2020. doi: 10.1016/j.jinf.2020.02.010

26. HARAPAN H, ITOH N, YUFIKA A, WINARDI W, et al. Coronavirus disease 2019 (COVID-19): A literature review. J Infect Public Heal. 2020. doi: https://doi.org/10.1016/j.jiph.2020.03.019

27. HOU H, WANG T, ZHANG B, LUO Y et al. Detection of $\operatorname{IgM}$ and $\operatorname{IgG}$ antibodies in patients with coronavirus disease 2019. Clin Transl Immunol. 2020; 9(5), e1136. doi: https://doi.org/10.1002/cti2.1136

28. HUANG C, WANG Y, LI X, REN L, et al. Clinical features of patients infected with 2019 novel coronavirus in Wuhan, China. Lancet. 2020; 395(10223): 497-506. doi: https://doi.org/10.1016/S0140-6736(20) 30183-5

29. INDWIANI ASTUTI Y. Severe Acute Respiratory Syndrome Coronavirus 2 (SARS-CoV-2): An overview of viral structure and host response. Diabetes Metab Syndr. 2020. doi: https://doi.org/10.1016/j.dsx.2020. 04.020

30. JIANG S, XIA S, YING T, LU L. A novel coronavirus (2019-nCoV) causing pneumonia-associated respiratory syndrome. Cell Mol Immunol. 2020; 17(5): 554554. doi: https://doi.org/10.1038/s41423-020-0372-4

31. KANDEEL M, NAZAWI M. Virtual screening and repurposing of FDA approved drugs against COVID19 main protease. Life Sci. 2020; article no. 117627. doi: https://doi.org/10.1016/j.lfs.2020.117627
32. LI G, FAN Y, LAI Y, HAN T et al. Coronavirus infections and immune responses. J Med Virol. 2020; 92(4): 424-432. doi: https://doi.org/10.1002/jmv.25685

33. LI T, ZHANG Y, FU L, YU C et al. siRNA targeting the leader sequence of SARS-CoV inhibits virus replication. Gene Ther. 2005; 12(9): 751-761. doi: https://doi.org/10.1038/sj.gt.3302479

34. LIU R, HAN H, LIU F, LV Z et al. Positive rate of RT-PCR detection of SARS-CoV-2 infection in 4880 cases from one hospital in Wuhan, China, from Jan to Feb 2020. Clinica Chimica Acta. 2020. doi: https://doi.org/10.1016/j.cca.2020.03.009

35. LU H, STRATTON CW, TANG YW. Outbreak of Pneumonia of Unknown Etiology in Wuhan China: the Mystery and the Miracle. J Med Virol. 2020; 92(4): 401-402. doi: https://doi.org/10.1002/jmv.25678

36. LU R, ZHAO X, LI J, NIU $P$ et al. Genomic characterisation and epidemiology of 2019 novel coronavirus: implications for virus origins and receptor binding. Lancet. 2020; 395(10224): 565-574. doi: https://doi.org/10.1016/S0140-6736(20)30251-8

37. MASTERS PS. The molecular biology of coronaviruses. Adv Virus Res. 2006; 66: 193-292. doi: https://doi.org/10.1016/S0065-3527(06)66005-3

38. MOHAMED A, ALAWNA M. Role of increasing the aerobic capacity on improving the function of immune and respiratory systems in patients with coronavirus (COVID-19): A review. Diabetes Metab Syndr. 2020. doi: https://doi.org/10.1016/j.dsx.2020.04.038

39. MOMATTIN H, AL-ALI AY, AL-TAWFIQ JA. A Systematic Review of therapeutic agents for the treatment of the Middle East Respiratory Syndrome Coronavirus (MERS-CoV). Travel Med Infect Dis. 2019; 30: 9-18. doi: https://doi.org/10.1016/j.tmaid. 2019.06.012

40. MORSE SS, MAZET JA, WOOLHOUSE M, PARRISH CR et al. Prediction and prevention of the next pandemic zoonosis. Lancet. 2012; 380(9857): 1956-1965. doi: https://doi.org/10.1016/S0140-6736 (12)61684-5

41. MOUSAVIZADEH L, GHASEMI S. Genotype and phenotype of COVID-19: Their roles in pathogenesis. J Microbiol Immuno Infect. 2020. doi: https://doi.org/ 10.1016/j.jmii.2020.03.022

42. NICOLA D, VITO M, LINDA JS, CANIO B. COVID-19 from veterinary medicine and one health perspectives: What animal coronaviruses have taught us. Res Vet Sci. 2020. doi: 10.1016/j.rvsc.2020.04.009

43. PARASKEVIS D, KOSTAKI EG, MAGIORKINIS G, PANAYIOTAKOPOULOS $\mathrm{G}$ et al. Full-genome evolutionary analysis of the novel corona virus (2019$\mathrm{nCoV}$ ) rejects the hypothesis of emergence as a result of a recent recombination event. Infect Genet Evol. 2020; 79: article no. 104212. doi: https://doi.org/ 10.1016/j.meegid.2020.104212

44. PATEL A, JERNIGAN DB. Initial public health response and interim clinical guidance for the 2019 
novel coronavirus outbreak - United States, December 31, 2019 - February 4, 2020. Morb Mortal Wkly Rep. 2020; 69(5): 140. doi: https://doi.org/10.15585/mmwr. mm6905e1

45. PAWAR AY. Combating Devastating COVID-19 by Drug Repurposing. Int J Antimicrob Ag. 2020. doi: https://doi.org/10.1016/j.ijantimicag.2020.105984

46. ROLAIN JM, COLSON P, RAOULT D. Recycling of chloroquine and its hydroxyl analogue to face bacterial, fungal and viral infections in the $21^{\text {st }}$ century. Int Antimcirob Ag. 2007; 30(4): 297-308. doi: https://doi.org/10.1016/j.ijantimicag.2007.05.015

47. SERAFIN MB, BOTTEGA A, FOLETTO VS, DA ROSA TF et al. Drug repositioning an alternative for the treatment of coronavirus COVID-19. Int Antimcirob Ag. 2020; article no. 105969. doi: https://doi.org/10.1016/j.ijantimicag.2020.105969

48. TANG T, BIDON M, JAIMES JA, WHITTAKER GR et al. Coronavirus membrane fusion mechanism offers as a potential target for antiviral development. Antivir Res. 2020; article no. 104792. doi: https://doi.org/ 10.1016/j.antiviral.2020.104792

49. THEEL ES, SLEV P, WHEELER S, COUTURIER MR et al. The role of antibody testing for SARSCoV-2: is there one?. J Clin Microbiol. (2020). doi: https://doi.org/10.1128/JCM.00797-20

50. TONG TR. Severe Acute Respiratory Syndrome Coronavirus (SARS-CoV). Perspect Med Virol. 2006; 16: 43-95. doi: https://doi.org/10.1016/S01687069(06)16004-8

51. TOTURA AL, BARIC RS. SARS coronavirus pathogenesis: host innate immune responses and viral antagonism of interferon. Curr Opin Virol. 2012; 2(3): 264-275. doi: https://doi.org/10.1016/j.coviro.2012. 04.004

52. VALLAMKONDU J, JOHN A, WANI WY, RAMADEVI S et al. SARS-CoV-2 pathophysiology and assessment of coronaviruses in CNS diseases with a focus on therapeutic targets. BBA Mol Basis Dis. 2020; 165889. doi: https://doi.org/10.1016/j.bbadis. 2020.165889

53. WANG D, HU B, HU C, ZHU F et al. Clinical characteristics of 138 hospitalized patients with 2019 novel coronavirus - infected pneumonia in Wuhan,
China. J Am Med Assoc. 2020; 323(11): 1061-1069. doi: https://doi.org/10.1001/jama.2020.1585

54. WANG H, YANG P, LIU K, GUO F et al. SARS coronavirus entry into host cells through a novel clathrin-and caveolae-independent endocytic pathway. Cell Res. 2008; 18(2): 290-301. doi: https://doi.org/ 10.1038/cr.2008.15

55. WANG LS, WANG YR, YE DW, LIU QQ. A review of the 2019 Novel Coronavirus (COVID-19) based on current evidence. Int J Antimicrob Ag. 2020; article no. 105948. doi: https://doi.org/10.1016/j.ijantimicag. 2020.105948

56. WANG M, CAO R, ZHANG L, YANG X et al. Remdesivir and chloroquine effectively inhibit the recently emerged novel coronavirus (2019-nCoV) in vitro. Cell Res. 2020; 30(3): 269-271. doi: https://doi.org/10.1038/s41422-020-0282-0

57. WANG Z, MA W, ZHENG X, WU G et al. Household transmission of SARS-CoV-2. J Infect. 2020. doi: https://doi.org/10.1016/j.jinf.2020.03.040

58. World Health Organization. (2020). Laboratory testing for coronavirus disease 2019 (COVID-19) in suspected human cases: interim guidance, March 22020 (No. WHO/COVID-19/laboratory/2020.4). World Health Organization.

59. WU D, WU T, LIU Q, YANG Z. The SARS-CoV-2 outbreak: what we know. Int J Infect Dis. 2020. doi: https://doi.org/10.1016/j.ijid.2020.03.004

60. XU X, HAN M, LI T, SUN W et al. Effective treatment of severe COVID-19 patients with tocilizumab. Proc Natl Acad Sci. 2020; 117(20): 10970-10975. doi: https://doi.org/10.1073/pnas.2005615117

61. XU Z, PENG C, SHI Y, ZHU Z et al. Nelfinavir was predicted to be a potential inhibitor of 2019-nCov main protease by an integrative approach combining homology modelling, molecular docking and binding free energy calculation. BioRxiv. 2020. doi: https://doi.org/10.1101/2020.01.27.921627

62. ZHOU P, YANG XL, WANG XG, HU B et al. Discovery of a novel coronavirus associated with the recent pneumonia outbreak in humans and its potential bat origin. BioRxiv. 2020. doi: 10.1101/2020.01. 22.914952 